\title{
Factors Affecting Millennials' Attitudes toward Luxury Fashion Brands: A Cross-Cultural Study
}

\author{
Regina Burnasheva ${ }^{1}$, Yong GuSuh ${ }^{2} \&$ Katherine Villalobos-Moron ${ }^{3}$ \\ ${ }^{1}$ PhD Candidate, Sookmyung Women's University, Seoul, Republic of Korea \\ ${ }^{2}$ Professor of Marketing, Sookmyung Women's University, Seoul, Republic of Korea \\ ${ }^{3}$ Assistant Professor, Namseoul University, Chungnam, Republic of Korea \\ Correspondence: Regina Burnasheva, PhD Candidate, Sookmyung Women's University, Cheongpa-ro 47-gil 100, \\ Seoul, Republic of Korea.
}

Received: April 29, 2019

Accepted: May 16, $2019 \quad$ Online Published: May 17, 2019

doi:10.5539/ibr.v12n6p69

URL: https://doi.org/10.5539/ibr.v12n6p69

\begin{abstract}
The millennials are an important cohort in luxury market, because of their purchasing power and the power of social media interaction. However, little is known about factors underlying their attitudes toward luxury fashion brands and online purchase intentions. This study explores whether materialism, a need for uniqueness, susceptibility to informative influence, and social media usage affect millennials' attitudes toward luxury fashion brands and online purchase intentions. In addition, this research examines cross-cultural differences between Russian and Korean millennials based on four cultural dimensions of Hofstede's model. The results indicated that all factors significantly related to attitudes towards luxury brands, and this, in turn, positively effect on online purchase intentions. Moreover, the results indicated that millennials from Korea and Russia pursue a need for uniqueness, some differences were revealed regarding materialism, susceptibility to informative influence and social media usage. Theoretical and practical implications are further discussed.
\end{abstract}

Keywords: luxury fashion brands, millennials, materialism, need for uniqueness, susceptibility to informative influence, social media usage

\section{Introduction}

The millennials are an important generational group of consumers who purchase luxury online and therefore to determine their attitude to luxury has become an important subject for this study. Moreover, the millennials have different attitudes compared to other groups. They are very savvy in the usage of new technologies and they are more concerned in online behavior like online shopping (Klapilova, 2016) where their purchasing rate is ranked to be the highest (Dhanapal et al., 2015).

With the increasing purchases of luxury brands online by millennials, it has become highly necessary to understand factors underlying millennials' attitudes toward luxury fashion brands from a cross-cultural context. There are a lot of studies about millennials' attitudes toward luxury brands from U.S (Beaudoin et al., 2003), China (Zhan and He, 2012), Brazil (Gil et al., 2012), but there is no study relating to South Korea and Russia. There are several reasons why we chose to compare these two countries. First, South Korea and Russia are both fast-growing luxury markets and are the biggest ecommerce markets in the world. The luxury market in Korea is very sizable and has good growth opportunities. In 2016, amounting to the US\$11 billion, luxury supplies represent $3 \%$ of the worldwide luxury goods market and it is ranked the fourth highest growing luxury supplies market next to India, Malaysia and Indonesia (Luxury Society, 2017). The luxury market in Russia is roughly at $€ 3.5$ billion which already comprises $1.4 \%$ of luxury worldwide sales (Contactlab, Exane BNP Paribas, 2016). Moreover, South Korea and Russia are in top ten of the biggest ecommerce markets in the world, with annual sales of US\$37 billion and US\$20, respectively (business.com, 2017). Second, South Korea and Russia are culturally different countries. To date, no research has yet been found to explore factors driving attitudes toward luxury fashion brands within two countries, Russia and South Korea.

Using social comparison and social impact theories, this study describes conformity (materialism, susceptibility to informative influence, social media usage) and nonconformity (need for uniqueness) behaviors driving millennials' attitudes toward luxury brands across cultures. Social comparison and social impact theories 
underpinning a theoretical model of current research because they suggest that people interact, compare themselves with others and form their attitude through social impact and comparison (Festinger, 1954; Latane, 1981).

Prior studies have investigated many various factors driving attitudes toward luxury brands, including the need for uniqueness (Gentina et al., 2015; Bian and Forsythe, 2012), materialism (Gil et al., 2012; Kim et al., 2012), susceptibility to influence (Gentina et al., 2015; Zhan and He, 2012), brand consciousness (Zhang and Kim, 2013), self-monitoring (Bian and Forsythe, 2012), experiential needs (Kim et al., 2012), social media usage (Kamal et al., 2013); but, there is a gap in the literature to taken four factors (materialism, need for uniqueness, susceptibility to informative influence, social media usage) together as influencing factors affecting attitudes toward luxury goods in the context of cross-cultural.

Therefore, the aim of this research is to simultaneously explore four influencing factors - materialism, need for uniqueness, susceptibility to informative influence, social media usage - that act as independent variables of millennials' attitudes toward brands of luxury fashion and online buying intentions. Moreover, this study is designed to examine whether there are cross-cultural differences in four aforementioned factors.

This paper contributes to prior literature in two important ways. First, this research is offering a framework that shows how four factors simultaneously affect millennials' attitudes concerning luxury brands and its online purchase intentions. Second, the findings will enable marketers of luxury fashion brands to understand cross-cultural differences in influencing factors driving millennials' attitude about luxury fashion goods and develop appropriate strategies that would increase the sales among this target group online.

\section{Theoretical Background and Hypotheses}

\subsection{Materialism}

Materialism is defined as a personality-like character of people who view possessions as necessary to their identities and lives (Belk, 1984). An increase usage of luxury goods is due to the high materialism which is led by growing need for sophisticated possessions. Thus, recent studies demonstrate impact of materialism on attitude and purchase intention towards luxury within online and offline contexts (Kamal et al., 2013; Park et al., 2007; Gil et al., 2012; Kim et al., 2012; Prendergast and Wong, 2003).

Richins (1994) suggests that highly materialistic individuals tend to give more importance on expensive and publicly displayed ownership objects, which represents social status and success. They are anxious with their living status judgment which tend them to compare more both cognitive and affective contexts with others (Atay et al., 2009). Social Comparison Theory connotes that in order to establish social status; people tend to compare their own material acquisitions with the possession of significant others (Chan and Prendergast, 2008). This theory provides a crucial grounding for understanding the effect of materialism on millennials' attitudes toward luxury brands. Millennials are more materialistic, status-seeking and are more prone to social comparison than previous generations. Based upon the aforementioned arguments, this research hypothesizes:

H1: The higher the need for materialism leads to have more positive millennials' attitude toward luxury brands.

\subsection{Need for Uniqueness}

The need for uniqueness is the need of a person to convey his/her uniqueness from others - to be dissimilar and not "just another face in the crowd" (Fromkin, 1972; Snyder and Fromkin, 1980). This study builds on social comparison theory to lead individuals compare themselves with others to satisfy the need for being different. Clients look for the improvement of their both personal and social images by using the status meanings of the goods they buy. This indicates that categories of goods, brands, and styles are utilized to fulfilling clients' need for uniqueness. In order to identify their characteristics and to establish unique identities, individuals buy luxury brands as what they own defines them (Belk, 1988). Because luxury brands are naturally in short supply due to their high price and limited distribution leading to have uniqueness context (Snyder and Fromkin, 1980; Vigneron and Johnson, 2004). Thus, consumers with high needs for uniqueness prefer unique brands (Tian and McKenzie, 2001) and have a more likely behavior concerning a good with a first-class price (Woodside, 2012). Based upon the arguments above, this research hypothesizes:

H2: The higher the need for uniqueness leads to have more positive millennials' attitude toward luxury brands.

\subsection{Susceptibility to Informative Influence}

The current study based on social impact and social comparison theories to explain the effect of susceptibility to informative influences on millennials' attitude concerning luxury brands. Susceptibility to informative influence is the inclination to examine peers, search for information from them and accept it as honest and realistic for 
making sound decisions (Mishra et al., 2017; Bearden et al., 1989). In online environments, information can be collected from others, manufacturer or retailer and neutral or third party (Chen et al., 2016). Millennials get information regarding fashion selections from their peers, brands on social media and even from famous celebrities. These recommendations can help them to develop brand attitudes. Moreover, as millennials post their item ratings, reviews and online experiences (Bedard and Tolmie, 2018) they are often well-informed on items that being bought by others. As was found in prior studies, susceptibility to informative influence can be highly impactful in decision-making processes and it has a significant effect on attitude toward the brand (Gentina et al., 2016; Chen et al., 2016). Based upon the arguments above, this research hypothesizes:

H3: The higher the need for susceptibility to informative influence leads to have more positive millennials' attitude toward luxury brands.

\subsection{Social Media Usage}

Social media usage has primarily changed the buyers' platform, and for brands to keep up with the trend, they are required to become accustomed without delay to both changing consumer attitudes and advancing technologies. Previous studies show measuring social media usage has two dimensions. First dimension comprises the types of actions such as contributing, sharing, consuming, searching, participating while the second dimension covers usage intensity such as frequency and duration (Bolton et al., 2013). The current study investigates social media usage through types of activities. As intensity of social media use increases, the main goal for luxury brands' engagement with social media is the appeal of luxury among millennials.

Through the lens of social comparison and social impact theories, this study attempts to explore the association between social media usage and millennials' attitude toward luxury brands. Social Impact Theory states that social influence affects changes in behavior and beliefs of persons after having interaction with other people (Cialdini and Trost, 1998; Cialdini and Goldstein, 2004). As social media gives users access with their friends and others, they tend to do comparison which will result to increased usage of social media (Chu et al., 2013), and thus, through this comparison individuals can develop their attitudes toward brands. Due to social networks, millennials are connected with each other's and comments/reviews of their peers related to decision-making are vital to them.

Millennials' usage of social media is becoming a vital factor in decision-making process. Previous studies have shown positive relationships between millennial's social media usage and buying intention concerning luxury items (Chu and Kamal, 2011), attitudes towards social media advertising (Kamal et al., 2013). Jin (2012) claimed that consumers who were overwhelmed with a well-known Facebook page of the luxury item showed positive attitudes concerning a luxury item, and this has been considered as one of the factors of customers' intention to use Facebook for online shopping and explore this network before doing a final purchase. Hence, this research hypothesizes:

H4: The higher the social media usage leads to have more positive millennials' attitude towards luxury fashion brands.

\subsection{Attitude and Online Purchase Intention}

Fishbein and Ajzen (1975) asserted that attitudes can be explained as a cultivated inclination to react in a consistently favorable or unfavorable ways with respect to a certain thing. The cognitive hierarchy framework of Homer and Kahle (1988) suggests that favorable actions are the result of attitude. This has been supported in recent studies indicating a positive connection between attitude and intention (Ha and Janda, 2012), and is further explained by Ajzen and Fishbein (1980) in their Theory of Reasoned Action. According to this framework, a person's behavioral actions rely on his or her attitude concerning the subjective norms and actions related with behavior (Fishbein and Ajzen, 1975). In line with past research maintaining that the positive association between attitude and intention (Bian, 2010; Dabholkar and Bagozzi, 2002; Sheppard et al., 1988), this study hypothesizes that:

H5: Attitude towards luxury fashion brands is positively related to online purchase intention.

\subsection{Cultural Differences}

Cultural differences affect consumers' attitudes and behaviors (Aaker, 2000). The South Korea and Russia were chosen for this research as these two countries ranked similar in consumption of luxury fashion brands but differ in national culture. To further explain cross-cultural differences, the Hofstede model of national culture was used. This model claims that national culture portrays the norms, values and beliefs that are present within the people of a self-governing country (Schein, 2010; Hofstede et al. 2010). This study selected four dimensions of Hofstede's (2001) model of national culture: masculinity, individualism, power distance and uncertainty 
avoidance. All these four dimensions were coupled with materialism, need for uniqueness, susceptibility to informative influence and social media usage.

Materialism is closely related with masculinity. Ogden and Cheng (2011) pointed out that masculinity is related with the aspect of success and high degree of materialism. Zinkhan and Prenshaw (1994) state that high level of masculinity is representing importance of an achievement, money and material things, growth and performance. This implies that individuals belonging to high masculinity culture evaluate material possessions more than those belonging to low masculinity culture. According Hofstede's (2001) model (Table 1), Koreans have higher masculinity scores than Russians. Yoon (2003) has asserted that Korean people since 1995 particularly the younger generations have been profiled materialistic. They consider money as the status symbol for success and giving much importance on acquiring luxury items which they can boast to others. De Mooij (2004) has added that luxury brands represent the individual's material success and this is more prevalent on the people from the masculine cultures than the feminine cultures. Based on Hofstede's (2001) model and the arguments above, this research hypothesizes:

H6: Korean millennials will demonstrate a higher materialism than Russian millennials.

There is congruence between need for uniqueness and individualism. Traditionally, collectivistic or eastern culture has been known to have different luxury goods purchase behavior from individualistic or western societies (Nancy and Aaron, 1998). Collectivists are more inclined to the interpersonal - oriented construal of personality; their emphasis is on the perceptions of the public and outer personality in buying luxury brands. On the other hand, individualistic customers buy luxury items for satisfaction and personal wants as they give high importance on their self-independence (Lee et al., 2014). But aspects of individualism and collectivism can also be different in a culturally similar society (Oyserman et al., 2002). According to Hofstede (2001) scores (Table 1), Russia is collectivistic country, but at the same time, Russians do not give up their interests (Naumov and Petrovskaya, 2010) and prefer to avoid similarity regarding purchasing of luxury goods (Kaufmann et al., 2012). Based on Hofstede's model and arguments above, this research hypothesizes:

H7: Russian millennials will demonstrate a higher need for uniqueness than Korean millennials.

There is compatibility between susceptibility to informative influence and power distance. Susceptibility to informative influence, explains that people are not really having an inclination to look for and accept information from individualistic orientation but from their interpersonal sources (Mourali et al., 2005) and power distance was more expected to have an impact on interpersonal sources' usage than individualism-collectivism (Dawar et al., 1996). Lam et al., (2009) claimed that individuals in high-power distance cultures are more involved in getting information than people in low-power distance cultures. According to Hofstede's (2001) index (Table 1), Russia represents high power distance scores than Korea, and would therefore show a higher tendency towards susceptibility to informative influence. Based on the above discussion, this research hypothesizes:

H8: Russian millennials will demonstrate a higher susceptibility to informative influence than Korean millennials.

Finally, social media usage is associated with uncertainty avoidance. Dadgar et al., (2017) have asserted that people whose uncertainty avoidance is high will utilize social media to search for more information to lessen uncertainty and difficulty and concluded that the higher degree of uncertainty avoidance will lead to more social media usage. Hudson et al., (2015) indicate that if uncertainty of avoidance is high, individuals tend to lessen the risks by doing constant social communications while if there is a low uncertainty avoidance, this behavior is not that much prevalent. Moreover, members who belong to high uncertainty avoidance group are more expected to be inclined in the details from legit and knowledgeable sources on social media. On the contrary, people from the lower uncertainty avoidance tend to focus more into wider references of opinions and ideas (Lin et al., 2017). With the growing demand to acquire reliable information related with luxury fashion items of the millennials, social media can be considered as a beneficial tool for them to search for details, since this platform has the ability to generate quick connection between the clients and brands ( $\mathrm{Li}$ and Mousseaux, 2013). According to Hofstede's (2001) model (Table 1), South Korea has lower uncertainty avoidance scores than Russia. Consequently, based on Hofstede's model and arguments above, this research hypothesizes:

H9: Russian millennials will demonstrate a higher social media usage than Korean millennials. 
Table 1. Hofstede's scores for Russia and South Korea

\begin{tabular}{|c|c|c|c|c|}
\hline \multicolumn{5}{|c|}{ Hofstede national culture dimensions } \\
\hline & Power distance & Uncertainty avoidance & Individualism & Masculinity \\
\hline Russia & 93 & 95 & 39 & 36 \\
\hline South Korea & 60 & 85 & 18 & 39 \\
\hline
\end{tabular}

\section{Method}

\subsection{Data Collection}

This study was focused on handbags as this category still make up the bulk of global luxury purchases and remained the top category sold online (Bain and Company, 2017). A pre-test was conducted to choose the brands for this research. The top ten luxury brands for handbags were obtained from Brand Finance's (2017) Global 500 report and the bestseller product with price ranges for each luxury brand were shown to 15 millennials in Korea and Russia. Participants were asked to rate brands according to the familiarity. Finally, 5 luxury brands for handbags (Louis Vuitton, Gucci, Coach, Prada, Chanel) were chosen and used for this study.

An online survey was performed as main test to analyze the hypotheses. The survey was first produced in Russian and was later translated to Korean and then back-translated into Russian by a bilingual person. In order to confirm the accuracy of the translation the author was cross-checked the original and back-translated versions. A total of 300 Russian and 301 Korean millennials be involved in the research from September to November 2018. Data in South Korea was selected through true research portal Dooit survey while data in Russia by posting the survey link on Facebook group pages. (Table 2) presents the demographic profile of respondents.

Table 2. Profiles of respondents.

\begin{tabular}{|c|c|c|}
\hline \multirow[t]{2}{*}{ Characteristic } & \multicolumn{2}{|l|}{ Frequency $(\%)$} \\
\hline & $\operatorname{Russia}(\mathrm{N}=300)$ & Korea $(\mathrm{N}=301)$ \\
\hline \multicolumn{3}{|l|}{ Gender } \\
\hline Male & $82(27.3 \%)$ & $84(27.9 \%)$ \\
\hline Female & $218(72.7 \%)$ & $217(72.1 \%)$ \\
\hline \multicolumn{3}{|l|}{ Age } \\
\hline $20-29$ & $143(47.7 \%)$ & $97(32.2 \%)$ \\
\hline $30-39$ & $157(52.3 \%)$ & $204(67.8 \%)$ \\
\hline \multicolumn{3}{|l|}{ Monthly Income Level } \\
\hline Less than 2000USD & $171(57.0 \%)$ & $86(28.6 \%)$ \\
\hline 2001-4000USD & $119(39.7 \%)$ & $147(48.8 \%)$ \\
\hline More than 4001USD & $10(3.3 \%)$ & $68(22.6 \%)$ \\
\hline \multicolumn{3}{|l|}{ Education } \\
\hline High school & $1(0.3 \%)$ & $43(14.3 \%)$ \\
\hline College & $78(26.0 \%)$ & $46(15.3 \%)$ \\
\hline University & $221(73.7 \%)$ & $212(70.4 \%)$ \\
\hline \multicolumn{3}{|l|}{ Occupation } \\
\hline Student & $95(31.7 \%)$ & $26(8.6 \%)$ \\
\hline Businessman & $42(14.0 \%)$ & $21(7.0 \%)$ \\
\hline Employee & $122(40.7 \%)$ & $192(63.8 \%)$ \\
\hline Other & $41(13.7 \%)$ & $62(20.6 \%)$ \\
\hline \multicolumn{3}{|c|}{ How much do you spend on luxury goods online per one time? } \\
\hline Less than 1000USD & $204(68.0 \%)$ & $165(54.8 \%)$ \\
\hline 1001-4000USD & $88(29.3 \%)$ & $122(40.5 \%)$ \\
\hline More than 4001USD & $8(2.7 \%)$ & $14(4.7 \%)$ \\
\hline \multicolumn{3}{|c|}{ How often do you purchase luxury goods online in a year? } \\
\hline Once & $122(40.7 \%)$ & $151(50.2 \%)$ \\
\hline 2 times & $114(38.0 \%)$ & $105(34.9 \%)$ \\
\hline More than 3 times & $64(21.3 \%)$ & $45(15.0 \%)$ \\
\hline
\end{tabular}

Percentage of female respondents was high, with more than $70 \%$ in Russia and South Korea. As for age group, the dominant group of the respondents was between 20-29 (47.7\%) in Russia, and 30-39 (67.8\%) in South Korea. Concerning the monthly income level, the biggest group had less than 2000USD (57\%) for the Russian sample, and 2001-4000USD (48.8\%) for the South Korean sample. The Russian and Korean samples present a high level of education, with more than $70 \%$ obtaining university degree. In terms of occupation, the majority of the respondents, in both countries, were employee. The Russian and Korean respondents spend less than 1000USD on luxury goods online per one time, with $68 \%$ and $54.8 \%$, respectively. Moreover, almost more than half of the Russian and Korean respondents purchase luxury goods online once a year.

The collected data were analyzed using the AMOS 24.0 program for SEM analysis to examine the impact of factors on millennials' attitudes toward luxury fashion brands and online purchase intentions. Moreover, 
MANOVA analysis were conducted to examine cross-cultural differences.

\subsection{Instrument Design}

The questionnaire of the research included two sections which started with a screening question to assure that all participants had experience with purchasing luxury brands online during the past 12 months.

The first section contained questions about consumers' demographic characteristics such as gender, age, monthly income level, education, occupation and also included questions about participants' online purchasing behavior.

The second part consisted 12 statements that ask about factors of luxury fashion brands (materialism, need for uniqueness, susceptibility to informative influence, and social media usage). Measures for factors were rated on a seven-point Likert scale, which ranged from 1 being "Strongly Disagree" and 7 being "Strongly Agree". Materialism was measured by 3 statements revised from Richins (2004) and Prendergast and Wong (2003). Statements to measure need for uniqueness were developed from Tian et al., (2001) scale. The measure of susceptibility to informative influence depended on Bearden at al., (1989) measuring model. Social media usage was measured using 3 statements adopted from Jin (2012), Wang et al., (2012), and Hughes et al., (2012).

Finally, 6 statements to measure millennials' attitudes (Spears and Singh, 2004) toward luxury brands and online purchase intentions (Korzaan, 2003; Lee and Lee, 2015; Summers, 2006) were used in this research.

\section{Results}

\subsection{Measure Reliability and Validity}

As a first step, before performing exploratory factor analysis, factorability of data was affirmed. The adequacy of sampling was tested by the Kaiser-Meyer-Olkin (KMO) (greater than 0.6), while the strength of the relationship by the Bartlett's test for sphericity of data (should be significant). According to results, all statements were found to be appropriate for the exploratory factor analysis $(\mathrm{KMO}=0.912$; Barlett's test significant, $\mathrm{p}=.00)$. An exploratory factor analysis using principal component method with varimax rotation demonstrated that six factors illustrating high levels of exploratory power (83.786\%). In addition, Cronbach's alpha values were greater than 0.7 (Nunnaly, 1978), ranging from 0.85 to 0.93 , which suggested high degrees of internal consistency.

The next step was to analyze confirmatory factor analysis using AMOS 24. Following Hair et al.'s (2009) criteria for acceptable range $(\mathrm{CMIN} / \mathrm{df}<3.0$, CFI $>.90$, NFI $>.90$, TLI $>.90$, RMSEA $<.80)$ this analysis demonstrates a good fit for the measurement model $(\mathrm{CMIN} / \mathrm{df}=2.678, \mathrm{CFI}=.978, \mathrm{NFI}=.965$, TLI $=.971$, RMSEA $=.053$ ). Three criteria of Fornell and Larcker (1981) were utilized to test convergent validity. 1) The factor loadings of all statements were more than 0.5 , ranging from 0.70 to $0.92 ; 2$ ) All factors had the average variance extracted (AVE) higher than 0.50 and composite reliability (CR) higher than 0.70 , ranging from 0.63 to 0.82 and from 0.84 to 0.93 , respectively (see Table 3 ); 3 ) Results of discriminant validity were under the average amount of variation in the dimensions square root of AVE. The square root of the AVE presented in (Table 4) were greater than its correlation estimates, confirming discriminant validity.

Table 3. Scale factor loadings

\begin{tabular}{|c|c|c|c|c|c|}
\hline Construct & Items & Factor loadings & Cronbach a & AVE & $\mathrm{CR}$ \\
\hline \multirow{3}{*}{ Materialism } & MAT1 & 0.85 & \multirow[t]{3}{*}{0.88} & \multirow[t]{3}{*}{0.63} & \multirow[t]{3}{*}{0.84} \\
\hline & MAT2 & 0.87 & & & \\
\hline & MAT3 & 0.81 & & & \\
\hline Need & NFU1 & 0.84 & \multirow[t]{3}{*}{0.85} & \multirow[t]{3}{*}{0.66} & \multirow[t]{3}{*}{0.85} \\
\hline \multirow[t]{2}{*}{ Uniqueness } & NFU2 & 0.91 & & & \\
\hline & NFU3 & 0.70 & & & \\
\hline Susceptibility & SII1 & 0.90 & \multirow{3}{*}{0.92} & \multirow[t]{3}{*}{0.77} & \multirow[t]{3}{*}{0.91} \\
\hline Inform. Influence & SII2 & 0.92 & & & \\
\hline Social Media & SII3 & 0.84 & & & \\
\hline \multirow[t]{3}{*}{ Usage } & SMU1 & 0.89 & \multirow[t]{3}{*}{0.92} & \multirow[t]{3}{*}{0.77} & \multirow[t]{3}{*}{0.91} \\
\hline & SMU2 & 0.90 & & & \\
\hline & SMU3 & 0.91 & & & \\
\hline \multirow[t]{3}{*}{ Attitude } & AT1 & 0.85 & \multirow[t]{3}{*}{0.88} & \multirow[t]{3}{*}{0.73} & \multirow[t]{3}{*}{0.89} \\
\hline & AT2 & 0.85 & & & \\
\hline & AT3 & 0.82 & & & \\
\hline Online Purchase & OPI1 & 0.92 & \multirow[t]{3}{*}{0.93} & \multirow[t]{3}{*}{0.82} & \multirow[t]{3}{*}{0.93} \\
\hline \multirow[t]{2}{*}{ Intention } & OPI2 & 0.91 & & & \\
\hline & OPI3 & 0.89 & & & \\
\hline
\end{tabular}

Notes. AVE=average variance extracted; $\mathrm{CR}=$ composite reliability 
Table 4. Discriminant validity analysis

\begin{tabular}{lllllll}
\hline Variable & MAT & NFU & SII & SMU & ATT & OPI \\
\hline MAT & $\mathbf{0 . 7 9 3}$ & & & & & \\
NFU & 0.418 & $\mathbf{0 . 8 1 2}$ & & & & \\
SII & 0.565 & 0.515 & $\mathbf{0 . 8 7 7}$ & $\mathbf{0 . 8 7 7}$ & & \\
SMU & 0.691 & 0.478 & 0.663 & 0.618 & $\mathbf{0 . 8 5 4}$ & $\mathbf{0 . 9 0 6}$ \\
ATT & 0.640 & 0.493 & 0.618 & 0.609 & 0.584 & \\
OPI & 0.583 & 0.359 & 0.431 & &
\end{tabular}

Notes. $* * *$ Correlation is significant at the 0.001 level.

Bolded diagonal elements are the square root of AVE.

\subsection{Hypotheses Testing}

As a first step, a structural model using the robust maximum likelihood estimation method was tested to analyze the relationships among variables demonstrated by $\mathrm{H} 1-\mathrm{H} 5$. The structural model indicated an acceptable fit to the data: $\mathrm{CMIN} / \mathrm{df}=2.854, \mathrm{CFI}=.976, \mathrm{NFI}=.964, \mathrm{TLI}=.967, \mathrm{RMSEA}=.056$. The results provided support for the following hypothesized relationships: materialism $(\mathrm{H} 1: \mathrm{t}=7.37, \mathrm{p}<.001)$, need for uniqueness $(\mathrm{H} 2 \mathrm{t} \mathrm{t}=$ $3.79, \mathrm{p}<.001)$, susceptibility to informative influence $(\mathrm{H} 3: \mathrm{t}=4.21, \mathrm{p}<.001)$, social media usage $(\mathrm{H} 4: \mathrm{t}=3.64$, $\mathrm{p}<.001)$ and attitude. The findings also supported for the existence of positive association between attitude and online purchase intention (H5: $\mathrm{t}=14.26, \mathrm{p}<.001)$. (see Table 5).

Table 5. Summary of hypotheses tests

\begin{tabular}{llll}
\hline Hypotheses & Beta & t-Value & Results \\
\hline H1: Materialism $\rightarrow$ Attitude & 0.29 & $7.37 * * *$ & Accepted \\
H2: Need for uniqueness $\rightarrow$ Attitude & 0.15 & $3.79 * * *$ & Accepted \\
H3: Susceptibility to inform. influence $\rightarrow$ Attitude & 0.16 & $4.21^{* * *}$ & Accepted \\
H4: Social media usage $\rightarrow$ Attitude & 0.15 & $3.64 * * *$ & Accepted \\
H5: Attitude $\rightarrow$ Online Purchase Intention & 0.96 & $14.26 * * *$ & Accepted \\
\hline
\end{tabular}

Notes. $* * * \mathrm{p}<0.001$

In the second step, a one-way multivariate analysis of variance (MANOVA) for the total set of variables was conducted to support H6 - H9 regarding cross-cultural differences in factors driving attitudes toward luxury brands. The independent variable was country (South Korea, Russia) and four dependent variables were used (materialism, need for uniqueness, susceptibility to informative influence, social media usage). The results of a one-way MANOVA revealed that the multivariate main effect for country was significant (Wilk's Lambda = $0.806, \mathrm{~F}(4,596)=35.87, \mathrm{p}<.001)$. The findings further indicated that three univariate $\mathrm{F}$ tests $(\mathrm{df}=1,599)$ ranged from $8.166(\mathrm{p}<0.01)$ for susceptibility to informative influence to $70.510(\mathrm{p}<.001)$ for materialism, showing significant differences between countries for each of the three factors. However, no significant difference was detected for the two countries in need for uniqueness.

To evaluate $\mathrm{H} 6-\mathrm{H} 9$ hypotheses, the scores of the both countries using four cultural dimensions of Hofstede's (2001) cultural index and mean scores using MANOVA technique were analyzed.

Hypothesis 6 predicted that Korean millennials would demonstrate a higher materialism than Russian millennials. Based on Hofstede's scores, Korea is more masculine than Russia which would be suggesting a higher materialism for Korean sample. However, on the basis of MANOVA mean scores, Russian millennials scored a higher mean $(M=0.325)$ than Korean millennials $(M=-0.324)$. Therefore, Hypothesis 6 was not supported.

Hypothesis 7 proposed that Russian millennials would demonstrate a higher need for uniqueness than Korean millennials. Nevertheless, Russian millennials and South Korean millennials did not differ in need for uniqueness. This can be explained by the fact that millennials are more individualistic in nature and need for uniqueness is universally significant among them. Thus, Hypothesis 7 was not supported.

Hypothesis 8 suggested that Russian millennials would demonstrate a higher susceptibility to informative influence than Korean millennials. Russia has more power distance than Korea, and consequently Russian millennials demonstrated higher mean scores $(M=0.116)$ for susceptibility to informative influence in comparison with mean scores of Korean millennials $(\mathrm{M}=-0.117)$, supporting Hypothesis 8 .

Hypothesis 9 expected that Russian millennials would demonstrate a higher social media usage than Korean millennials. Russia demonstrated to be a more uncertainty avoidance country than Korea, thus Russian millennials had a higher mean $(\mathrm{M}=0.274)$ for social media usage as compared to Korea mean scores $(\mathrm{M}=$ 0.273), validating Hypothesis 9 (see Table 6). 
Table 6. Summary of MANOVA results

\begin{tabular}{llll}
\hline Dependent variable & \multicolumn{2}{c}{ Mean scores (Standard deviation) } & F-value \\
& Korea & Russia & \\
\hline Materialism & $-0.324(1.033)$ & $0.325(0.851)$ & $70.510^{* * *}$ \\
Need for uniqueness & $-0.003(0.868)$ & $0.003(1.119)$ & 0.006 \\
Susceptibility to informative influence & $-0.117(1.193)$ & $0.116(0.745)$ & $8.265^{* *}$ \\
Social media usage & $-0.273(1.041)$ & $0.274(0.877)$ & $48.050^{* * *}$ \\
\hline
\end{tabular}

Notes. $* * \mathrm{p}<0.01 ; * * * \mathrm{p}<0.001$

To sum up, the results of a structural equation model (SEM) supported all hypotheses (H1 - H5) and found $\mathrm{t}$-values significant at $\mathrm{p}<0.001$. Furthermore, the results of MANOVA analysis supported two hypothesized relationships (H8, H9), and two hypotheses (H6, H7) were not validated.

\section{General discussion}

The aim of this research was to examine the effect of materialism, need for uniqueness, susceptibility to informative influence, social media usage on the millennials' attitudes toward luxury fashion brands across countries and its' impact on online purchase intentions.

Drawing on the Social Comparison Theory, Social Impact Theory and Theory of Reasoned Action, the findings showing that four factors significantly impact on attitudes towards luxury brands, and this, in turn, positively effect on online purchase intentions. From the theoretical point of view, the findings of this research contribute to consumer attitude literature by analyzing four factors together that seem to be valuable concept. In addition to the theoretical point of view, the results bear significant practical implication for luxury managers by showing that materialism is the strongest factor leading to positive millennials' attitudes toward luxury brands. Luxury managers should devote more attention to strategies focusing on materialism. For instance, marketing strategies utilizing hedonic appeals can be beneficial.

Further, cross-cultural differences were examined to compare millennials' behaviors across countries. Russia and South Korea are culturally different countries were chosen for comparison. By using cultural dimensions of Hofstede's (2001) model as a framework, four cultural dimensions (masculinity, individualism, power distance and uncertainty avoidance) were linked with four factors (materialism, need for uniqueness, susceptibility to informative influence and social media usage) in this study. The findings show that relative to Korean millennials, Russian millennials demonstrate higher susceptibility to informative influence and social media usage behaviors. However, the findings that Korean millennials demonstrate a higher materialism than Russian millennials were not supported. These unexpected findings can be explained by the fact that statistics do not always demonstrate the real picture of a country or culture. For example, Russia can be very materialistic and would be described as more masculine culture (Stoll, 2010). Due to the lack of research regarding millennials' behaviors and attitudes toward luxury brands in Russia, these findings make significant contribution to existing literature. From the practical point of view, luxury managers aiming to reach Russian millennials need to increase efforts to emphasize status of their brands.

In addition, findings from the present research show that need for uniqueness is evaluated similarly by millennials of Russia and South Korea. Two reasons for these unexpected findings may provide additional insight to the cross-cultural studies on consumer behavior among millennial generation. First, millennials around the world attach great importance to uniqueness and desire to look different from others by possessing exclusive luxury brands. Second, according to Hofstede (2001), Russia is similar to the South Korea in being collectivistic-oriented country, where priority is given to the goals of the collective over personal goals (Lee and Kacen, 2008). However, due to globalization, collectivist cultures may adopt some components of individualism without changing their collectivist nature (Brewer and Chen, 2007). In line with previous conclusions (Bian and Forsythe, 2012; Cha and Kwon, 2018), this study also expands research by providing results that millennials from Korea and Russia (collectivistic societies) pursue a need for uniqueness (individualistic element). Considering practical implication, luxury managers should take into consideration consumers' need for uniqueness when targeting millennials, regardless of national culture.

From the practical point of view, the findings provide significant considerations for luxury managers in terms of development of positive attitude strategies among Russian and Korean millennials. Specifically, managers of luxury brands need to adapt content of online store, depending on clients' country of origin through identifying IP address. In addition, luxury managers should be aware that development of positive attitudes among millennials can emerge from distinct social and individual behaviors based on culture. For instance, for millennials from high power distance and uncertainty avoidance countries (e.g. Russia) luxury managers should 
invest additional resources to social media use, social media strategies, investing in influencers, offering exclusive promotions (Bedard and Tolmie, 2018) and comprehensive information. Luxury companies could benefit by facilitating interactions between company and consumers through including a hyperlink on their website with consumers' trial experiences, assessment of their brands and ratings (Bei et al., 2004; Chen et al., 2016; Dellarocas, 2003). In addition, facilitating dialogue among consumers through creating more interesting or informed communities (chat room, forum, blogs) (Armstrong and Hagel, 2000) can be beneficial for luxury companies. To encourage millennials, luxury managers can offer rewards to users who create content for sharing information about brand. Thus, luxury managers need to be aware that millennials use social media and informational influences more in high power distance and high uncertainty avoidance countries, such as Russia. In sum, the understanding of millennials' behaviors may help luxury managers better segment their markets and direct marketing strategies accordingly.

A number of limitations in this study deserve consideration. First, as this study used cross-sectional design that can be condemned for not demonstrating causality (Echambadi et al., 2006), future research should utilize experimental or longitudinal design in order to reinforce the causal association between factors. Second, the factors in this study refers to the social and individual behaviors. Other psychological traits such as value consciousness (Zhan and He, 2012) and self-congruity (Liu et al., 2012) can be investigated in the future studies. Third, this study compared two different cultures, Russia and South Korea. In order to enhance credibility of the results, future research should replicate the same framework for reflecting wider demographic segments in more individualistic cultures, such as USA or UK.

\section{References}

Aaker, J. (2000). Accessibility or diagnosticity? Disentangling the influence of culture on persuasion processes and attitudes. Journal of Consumer Research, 26(4), 340-357. https://doi.org/10.1086/209567

Ajzen, I., \& Fishbein, M. (1980). Understanding attitudes and predicting social behavior. Prentice Hall, Englewood Cliffs, NJ.

Alvandi, M., Fazli, S., \& Najafi S. (2013). Investigating the impact of self on attitudes toward luxury brands among teens in Iran. International Research Journal of Applied and Basic Sciences, 5(7), 854-865.

Amaldoss, W., \& Jain, S. (2005). Pricing of conspicuous goods: A competitive analysis of social effects. Journal of Marketing, 42(1), 30-42. https://doi.org/10.1509/jmkr.42.1.30.56883

Armstrong, A., \& Hagel, J. (2000). The real value of online communities. In E. Lesser, M. A. Fontaine, and J. A. Lusher (Eds.), Knowledge and communities, (pp. 85-95). Boston: Butterworth-Heinemann. https://doi.org/10.1016/B978-0-7506-7293-1.50009-3

Atay, E. G., Sirgy, M. G., Cicic, M., \& Husic, M. (2009). Extending the research in relation to materialism and life satisfaction. Advances in Consumer Research, 39, 225-232.

Bain and Company (2017) Luxury goods worldwide market study. Available at http://www.bain.com/publications/articles/luxury-goods-worldwide-market-study-fall-winter-2017.aspx (Accessed December 22, 2017)

Bearden, W. O., Netemeyer, R. G., \& Teel, J. E. (1989). Measurement of consumer susceptibility to interpersonal influence. Journal of Consumer Research, 15(4), 473-481. https://doi.org/10.1086/209186

Beaudoin, M. J., Lachance, P., \& Robitaille, J. (2003). Adolescents' brand sensitivity in apparel: Influence of three socialization agents. International Journal of Consumer Studies, 27(1), 47-57. https://doi.org/10.1046/j.1470-6431.2003.00261.x

Bedard, S, A, N., \& Tolmie, C. R. (2018). Millennials' green consumption behaviour: Exploring the role of social media. Corporate Social Responsibility and Environmental Management, 25(6), 1388-1396. https://doi.org/10.1002/csr.1654

Bei, L. T., Chen, E. Y., \& Widdows, R. (2004). Consumers' online information search behavior and the phenomenon of search vs. experience products. Journal of Family and Economic Issues, 25(4), 449-467. https://doi.org/10.1007/s10834-004-5490-0

Belk, R. W. (1984). Three scales to measure constructs related to materialism: Reliability, validity, and relationships to measures of happiness. Advances in Consumer Research, 11(1), 291-297.

Belk, R. W. (1988). Possessions and the extended self. Journal of Consumer Research: An Interdisciplinary Quarterly, 15(2), 139-168. https://doi.org/10.1086/209154 
Bian, Q., \& Forsythe, S. (2012). Purchase intention for luxury brands: A cross cultural comparison. Journal of Business Research, 65(10), 1443-1451. https://doi.org/10.1016/j.jbusres.2011.10.010

Bolton, R. N., Parasuraman, A., Hoefnagels, A., Migchels, N., Kabadayi, S., Gruber, T., \& Solnet, D. (2013). Understanding Generation Y and their use of social media: A review and research agenda. Journal of Service Management, 24(3), 245-267. https://doi.org/10.1108/09564231311326987

Brand Finance (2017). Global 500: The annual report on the world's most valuable cosmetics brands. Available at: http://brandfinance.com/images/upload/global_500_2017_locked_website.pdf (Accepted February, 2017)

Brewer, M. B., \& Chen, Y. R. (2007). Where (Who) are collectives in collectivism? Toward conceptual clarification of individualism and collectivism. Psychological Review, 114(1), 133-151. http://dx.doi.org/10.1037/0033-295X.114.1.133

Business.com (2017). 10 of the largest ecommerce markets in the world by country. Richie Edquid. Available at: https://www.business.com/articles/10-of-the-largest-ecommerce-markets-in-the-world-b/ February 22, 2017).

(Accessed

Cha, Y., \& Kwon, Y. (2018). Why Korean young women consumers buy luxury goods? The influence of cultural orientation and media use. East Asian Journal of Business Management, 8(2), 23-32. https://doi.org/10.13106/eajbm.2018.vol8.no2.23

Chan, K., \& Prendergast, G. P. (2008). Social comparison, imitation of celebrity models and materialism among Chinese youth. International Journal of Advertising, 27(5), 799-826. https://doi.org/10.2501/S026504870808030X

Chen, J., Teng, L., Yu, Y., \& Yu, X. (2016). The effect of online information sources on purchase intentions between consumers with high and low susceptibility to informational influence. Journal of Business Research, 69(2), 467-475. https://doi.org/10.1016/j.jbusres.2015.05.003

Chu, C., \& Kamal, S. (2011). An investigation of social media usage, brand consciousness, and purchase intention towards luxury products among Millennials. Advances in Advertising Research, 179-190. https://doi.org/10.1007/978-3-8349-6854-8_12

Chu, S., Kamal, S., \& Kim, Y. (2013). Understanding consumers' responses toward social media advertising and purchase intention toward luxury products. Journal of Global Fashion Marketing, 4(3), 158-174. https://doi.org/10.1080/20932685.2013.790709

Cialdini, R. B., \& Goldstein, N. J. (2004). Social influence: Compliance and conformity. Annual Review of Psychology, 55, 591-621. https://doi.org/10.1146/annurev.psych.55.090902.142015

Cialdini, R. B., \& Trost, M. R. (1998). Social influence: Social norms, conformity and compliance. In D.T. Gilbert, S.T. Fiske, and G. Lindzey (Eds.), The handbook of social psychology, (pp. 151-192). New York, NY, US: McGraw Hill.

Contactlab, Exane BNP Paribas. (2016). Luxury in Russia: The comeback. London. Available from https://contactlab.com/en/more/reports/luxury-in-russia/ (Accessed 12. 2016).

Dabholkar, P. A., \& Bagozzi, R. (2002). An attitudinal model of technology-based self-service: Moderating effects of consumer traits and situational factors. Journal of the Academy of Marketing Science, 30(3), 184-201. https://doi.org/10.1177/0092070302

Dadgar, M., Vithayathil, J., \& Osiri, J. K. (2017, January). Social media usage and cultural dimensions: An empirical investigation. Proceedings of the $50^{\text {th }}$ Hawaii International Conference on System Sciences. https://doi.org/10.24251/HICSS.2017.271

Dawar, N., Parker, P. M., \& Price, L. J. (1996). A cross-cultural study of interpersonal information exchange. Journal of International Business Studies, 27(3), 497-516. https://doi.org/10.1057/palgrave.jibs.8490142

De Mooij, M. (2004). Consumer behavior and culture: consequences for global marketing and advertising. Thousand Oaks, CA: Sage.

Dellarocas, C. (2003). The digitization of word of mouth: Promise and challenges of online feedback mechanisms. Management Science, 49(10), 1407-1424. https://doi.org/10.1287/mnsc.49.10.1407.17308

Dhanapal, S., Vashu, D., \& Subramaniam, T. (2015). Perceptions on the challenges of online purchasing: A study from "baby boomers", generation "X" and generation "Y" point of views. Contaduría y Administración, 
60(1), 107-132. https://doi.org/10.1016/j.cya.2015.08.003

Echambadi, R., Campbell, B., \& Agarwal, R. (2006). Encouraging best practice in quantitative management research: An incomplete list of opportunities. Journal of Management Studies, 43(8), 1801-1820. https://doi.org/10.1111/j.1467-6486.2006.00660.x

Festinger, L. (1954). A theory of social comparison processes. Human Relations, 7(2), 117-140. https://doi.org/10.1177/001872675400700202

Fishbein, M., \& Ajzen I. (1975). Belief, attitude, intention, behavior: An introduction to theory and research. Reading, Mass: Addison-Wesley.

Fornell, C., \& Larcker, D. F. (1981). Evaluating structural equation models with unobservable variables and measurement error. Journal of Marketing Research, 18(1), 39-50. https://doi.org/10.2307/3151312

Fromkin, H. L. (1972). Feelings of interpersonal indistinctiveness: An unpleasant affective state. Journal of Experimental Research in Personality, 6(2-3), 178-185.

Gentina, E., Shrum, L., \& Lowrey, T. (2016). Teen attitudes toward luxury fashion brands from a social identity perspective: A cross-cultural study of French and U.S. teenagers. Journal of Business Research, 69(12), 5785-5792. https://doi.org/10.1016/j.jbusres.2016.04.175

Gil, L. A., Kwon, K. N., Good, L. K., \& Johnson, L. W. (2012). Impact of self on attitudes toward luxury brands among teens. Journal of Business Research, 65(10), 1425-1433. https://doi.org/10.1016/j.jbusres.2011.10.008

Ha, H. Y., \& Janda, S. (2012). Predicting consumer intentions to purchase energy-efficient products. Journal of Consumer Marketing, 29(7), 461-469. https://doi.org/10.1108/07363761211274974

Hair, J. F., Black, W. C., Babin, B. J., Anderson, R. E., \& Tatham, R. L. (2009). Multivariate data analysis (7 $7^{\text {th }}$ ed.), Prentice Hall, Upper Saddle River, NJ.

Hofstede, G. (2001). Culture's consequences: Comparing values, behaviors, institutions and organizations across nations (2nd ed.). Thousand Oaks, CA: Sage.

Hofstede, G., Hofstede, G. J., \& Minkov, M. (2010). Cultures and Organizations: Software of the mind. New York: McGraw-Hill.

Homer, P. M., \& Kahle, L. R. (1988). A structural equation test of the value-attitude-behavior hierarchy. Journal of Personality and Social Psychology, 54(4), 638-646. https://10.1037/0022-3514.54.4.638

Hudson, S., Huang, L., Roth, M., \& Madden, T. (2015). The influence of social media interactions on consumer-brand relationships: a three-country study of brand perceptions and marketing behaviors. International Journal of Research in Marketing, 33(1), 27-41. https://doi.org/10.1016/j.jiresmar.2015.06.004

Hughes, D. J., Rowe, M., Batley, M., \& Lee, A. (2012). A tale of two sites: Twitter vs. Facebook and the personality predictors of social media usage. Computer in Human Behavior, 28(2), 561-569. https://doi.org/10.106/j.chb.2011.11.001

Jin, S. (2012). The potential of social media for luxury brand management. Marketing Intelligence and Planning, 30(7), 687-699. https://doi.org/10.1108/02634501211273805

Kamal, S., Chu S. C., \& Pedram, M. (2013). Materialism, attitudes, and social media usage and their impact on purchase intention of luxury fashion goods among American and Arab young generations. Journal of Interactive Advertising, 13(1), 27-40. https://doi.org/10.1080/15252019.2013.768052

Kaufmann, H. R., Vrontis, D., \& Manakova, Y. (2012). Perception of luxury: Idiosyncratic Russian consumer culture and identity. European Journal Cross-Cultural Competence and Management, 2(3/4), 209-235. https://doi.org/10.1504/EJCCM.2012.052594

Kim, H., Ko, E., Xu, B., \& Han, Y. (2012). Increasing customer equity of luxury fashion brands through nurturing consumer attitude. Journal of Business Research, 65(10), 1495-1499. http://doi.org/10.1016/j.jbusres.2011.10.016

Klapilova, K. (2016). Generation Y attitudes towards shopping: A comparison of the Czech Republic and Slovakia. Journal of Competitiveness, 8(1), 38-54. https://doi.org/10.7441/joc.2016.01.03

Korzaan, M. L. (2003). Going with the flow: Predicting online purchase intentions. Journal of Computer Information Systems, 43(4), 25-31. https://doi.org/10.1080/08874417.2003.11647530 
Lam, D., Lee, A., \& Mizerski, R. (2009). The effects of cultural values on word-of-mouth communication. Journal of International Marketing, 17(3), 55-70. https://doi.org/10.1509/jimk.17.3.55

Latane, B. (1981). The psychology of social impact. American Psychologist, 36(4), 343-356. https://doi.org/10.1037/0003-066X.36.4.343

Lee, E., Edwards, S. M., Youn, S., \& Yun, T. (2014). Understanding the moderating effect of motivational values on young consumers' responses to luxury brands: A cross-cultural study of South Korea and the USA. Journal of Marketing Communications, 24(2), 103-124. https://doi.org/10.1080/13527266.2014.975830

Lee, J. A., \& Kacen, J. J. (2008). Cultural influences on consumer satisfaction with impulse and planned purchase decisions. Journal of Business Research, 61(3), 265-272. https://doi.org/10.1016/j.jbusres.2007.06.006

Lee, J., \& Lee, J. (2015). How purchase intention consummates purchase behaviour: The stochastic nature of product valuation in electronic commerce. Behaviour \& Information Technology, 34(1), 57-68. https://doi.org/10.1080/0144929X.2013.853837

Li, Y., \& Mousseaux, S. (2013). Luxury fashion brands on social media: A study of young consumers' perception. Masters Thesis fashion brand management, Sweden.

Lin, H. C., Swarna, H., \& Bruning, P. F. (2017). Taking a global view on brand post popularity: Six social media brand post practices for global markets. Business Horizons, 60(5), 621-633. https://doi.org/10.1016/j.bushor.2017.05.006

Liu, F., Li, J, Mizerski, D., \& Soh, H. (2012). Self-congruity, brand attitude, and brand loyalty: a study on luxury brands. European Journal of Marketing, 46(7/8), 922-937. https://doi.org/10.1108/03090561211230098

Luxury Society (2017). South Korea: The new market for luxury brands? Available at: https://www.luxurysociety.com/en/articles/2017/05/south-korea-new-market-luxury-brands/ (Accessed May 19, 2017).

Mishra, A., Maheswarappa, S. S., Maity, M., \& Samu, S. (2018). Adolescent's eWOM intentions: An investigation into the roles of peers, the Internet and gender. Journal of Business Research, 86, 394-405. https://doi.org/10.1016/j.jbusres.2017.04.005

Mourali, M., Laroche, M., \& Pons, F. (2005). Individualistic orientation and consumer susceptibility to interpersonal influence. Journal of Services Marketing, 19(3), 164-173. https://doi.org/10.1108/08876040510596849

Nancy, Y. W., \& Aaron, C. A. (1998). Personal taste and family face. Psychology \& Marketing, 15(5), 423-441. https://doi.org/10.1002/(SICI)1520-6793(199808)15:5<423::AID-MAR2>3.0.CO;2-9

Naumov, A., \& Petrovskaya, I. (2010). Evolution of national culture impact on managing business in Russia. Eurasian Review, 3, November, 76-87.

Nunnally, J. C. (1978). Psychometric theory. New York, N.Y: McGraw-Hill.

Ogden, H., \& Cheng, S. (2011). Cultural dimensions and materialism: Comparing Canada and China. Asia Pacific Journal of Marketing and Logistics, 23(4), 431-447. https://doi.org/10.1108/13555851111165011

Oyserman, D., Coon, H. M., \& Kemmelmeier, M. (2002). Rethinking individualism and collectivism: Evaluation of theoretical assumptions and meta-analyses. Psychological Bulletin, 128(1), 3-72. https://doi.org/10.1037/0033-2909.128.1.3

Park, H. J. Burns, L. D., \& Rabolt, N. J. (2007). Fashion innovativeness, materialism, and attitude toward purchasing foreign fashion goods online across national borders: The moderating effect of internet innovativeness. Journal of Fashion Marketing and Management: An International Journal, 11(2), 201-214. https://doi.org/10.1108/13612020710751383

Prendergast, G., \& Wong, C. (2003). Parental influence on the purchase of luxury brands of infant apparel: an exploratory study in Hong Kong. Journal of Consumer Marketing, 20(2), 157-169. https://doi.org/10.1108/07363760310464613

Richins, M. L. (1994). Valuing things: the public and private meanings of possessions. Journal of Consumer Research, 21(3), 504-521. https://doi.org/10.1086/209414

Richins, M. L. (2004). The material values scale: Measurement properties and development of a short form. Journal of Consumer Research, 31(1), 209-219. https://doi.org/10.1086/383436 
Schein, E. H. (2010). Organizational culture and leadership. San Francisco: Jossey-Bass.

Sheppard, B. H., Hartwick, J., \& Warshaw P. R. (1988). The theory of reasoned action: A meta-analysis of past research with recommendations for modifications and future research. Journal of Consumer Research, 15(3), 325-343. https://doi.org/10.1086/209170

Snyder, C. R, \& Fromkin, H. L. (1980). Uniqueness: The human pursuit of difference. New York: Plenum Press. https://doi.org/10.1007/978-1-4684-3659-4

Spears, N., \& Singh, N. S. (2004). Measuring attitude toward the brand and purchase intentions. Journal of Current Issues and Research Advertising, 26(2), 53-66. https://doi.org/10.1080/10641734.2004.10505164

Stoll, S. (2010). Cultural dimension as a factor of success. Bachelor's Thesis, Saimaa University of Applied Sciences.

Summers, T. A., Belleau, B. D., \& Xu, Y. (2006). Predicting purchase intention of a controversial luxury apparel product. Journal of Fashion Marketing and Management, 10(4), 405-419. https://doi.org/10.1108/13612020610701247

Tian, K. T., \& McKenzie, K. (2001). The long-term predictive validity of consumers' need for uniqueness scale. Journal of Consumer Psychology, 10(3), 171-193. https://doi.org/10.1207/s15327663jcp1003_5

Tian, K. T., Bearden, W. O., \& Hunter, G. L. (2001). Consumers' need for uniqueness: scale development and validation. Journal of Consumer Research, 28(1), 50-66. https://doi.org/10.1086/321947

Vigneron, F., \& Johnson, L. W. (2004). Measuring perceptions of brand luxury. Journal of Brand Management, 11(6), 484-506. https://doi.org/10.1057/palgrave.bm.2540194

Wang, X., Yu, C., \& Wei, Y. (2012). Social media peer communication and impacts on purchase intention: A consumer socialization framework. Journal of Interactive Marketing, 26(4), 198-208. https://doi.org/10.1016/j.intmar.2011.11.004

Woodside, A. G. (2012). Economic psychology and fashion marketing theory appraising Veblen's theory of conspicuous consumption. Journal of Global Fashion Marketing, 3(2), 55-60. https://doi.org/10.1080/20932685.2012.10593107

Yoon, K. (2003). The great changes in Korean lifestyle. Available at: www.lgad.co.kr/webzine/030102/study/study3.htm (Accessed 15.11.2014)

Zhan, L., \& He, Y. (2012). Understanding luxury consumption in China: Consumer perceptions of best-known brands. Journal of Business Research, 65, 1452-1460. https://doi.org/10.1016/j.jbusres.2011.10.011

Zhang, B., \& Kim, J. H. (2013). Luxury fashion consumption in China: Factors affecting attitude and purchase intent. Journal of Retailing and Consumer Services, 20, 68-79. https://doi.org/10.1016/j.jretconser.2012.10.007

Zinkhan, G. M., \& Prenshaw, P. J. (1994). Good life images and brand name associations: Evidence from Asia, America, and Europe. Association for Consumer Research, 21, 496 -500.

\section{Copyrights}

Copyright for this article is retained by the author(s), with first publication rights granted to the journal.

This is an open-access article distributed under the terms and conditions of the Creative Commons Attribution license (http://creativecommons.org/licenses/by/4.0/). 